\title{
Influence of anxiety on blood pressure and heart rate during dental treatment
}

\section{Influência da ansiedade na pressão arterial e frequência cardíaca durante o tratamento odontológico}

\begin{abstract}
Purpose: To evaluate the influence of anxiety on blood pressure and heart rate during dental care in patients of the Dentistry Clinic in Rio Preto University Center - UNIRP, São José do Rio Preto, São Paulo, Brazil.

Methods: A sample of 60 volunteers who sought for the dental screening service was selected. We used a scale to evaluate the volunteers' anxiety level. Blood pressure and heart rate of patients were also checked in different periods of the dental treatment.

Results: Most of the volunteers were women. The relation between anxiety and pain before treatment, revealed that 54 (90.0\%) had no pain. The patients had low anxiety towards the use of different anesthetic solutions used during dental procedures. There was no statistically significant difference concerning to systolic blood pressure at first and, after application of anesthetic, given the degree of anxiety. Heart rate does not change as a function of anxiety. There is a slight change in heart rate after anesthesia, and it soon gets back to normal.

Conclusion: There was no difference in behavior of systolic and diastolic blood pressure in relation to the anxiety level and pain, measured before, during and after the procedure. Heart rate did not change during dental treatment in the patient anxiety level.
\end{abstract}

Key words: Anxiety; blood pressure; heart rate; dental treatment

\section{Resumo}

Objetivo: Avaliar a influência da ansiedade detectadas por meio de uma escala de ansiedade sobre os níveis de pressão arterial e a frequência cardíaca, durante o atendimento odontológico de pacientes das Clínicas de Odontologia do Centro Universitário de São José do Rio Preto, São Paulo, Brasil.

Metodologia: Foram selecionados ao acaso 60 voluntários que receberam atendimento odontológico de urgência. Foi utilizada uma escala para avaliar o grau de ansiedade dos voluntários. Foi verificada também a pressão arterial e a frequência cardíaca dos pacientes em três períodos distintos: pré, trans e pós-anestesia odontológica.

Resultados: A ansiedade não foi afetada pelas faixas etárias, apenas pelo gênero. A ansiedade não deve ser uma barreira, entre profissional/paciente e, ainda, a ansiedade apresentada não é um sinal clínico levado em consideração para a aplicação de medidas de controle.

Conclusão: Não houve alteração da pressão arterial sistólica, diastólica e da frequência cardíaca em relação ao grau de ansiedade e dor e ao tipo de solução anestésica empregada.

Palavras-chave: Ansiedade; pressão arterial; taxa cardíaca; tratamento odontológico

\author{
Jean Carlos Fernandes Goulart a \\ Matheus Dias Pinheiro a \\ Rodrigo Ventura Rodrigues a \\ Fabiano de Sant'Ana dos Santos ${ }^{\text {b }}$ \\ Alex Tadeu Martins b \\ Fábio Luiz Ferreira Scannavino b
}

- Curso de Odontologia, Centro Universitário de Rio Preto, São José do Rio Preto, SP, Brasil

b Curso de Odontologia, Centro Universitário da Fundação Educacional de Barretos, Barretos, SP, Brasil

Correspondence:

Fabiano de Sant'Ana dos Santos

Av. 27 n० 931 - Centro

Barretos, SP - Brasil

Barretos, $14780-340$

E-mail: fss@uol.com.br

Received: May 4, 2011

Accepted: January 26, 2012

Conflict of Interests: The authors state that there are no financial and personal conflicts of interest that could have inappropriately influenced their work.

Copyright: (c) 2011 Goulart et al. licensee EDIPUCRS. This is an Open Access article distributed under the terms of the Creative Commons AttributionNoncommercial-No Derivative Works 3.0 Unported License. 


\section{Introduction}

Fear, anxiety, stress, and pain associated with dental treatment are emotions intrinsically linked to the unpleasant experiences that affect a great part of the population (1-3). Anxiety is a vague and still answer, an emotional state experienced by the patient that makes difficult the dental treatment, associating to multifactorial etiology of each individual, manifested in different ways (4-6). A resource used to minimize the feeling of anxiety in the patient is the anesthesia performed properly (7-8).

The American Dental Association and the American Cardiology Association highlight be important for the Dental Surgeon to know adverse reactions that may occur in patients who have cardiovascular diseases such as hypertension (9). The inclusion of the arterial blood pressure measurement and heart rate as routine practice is of extreme importance to prevent possible complications during dental procedures $(7,10)$.

This study aims to evaluate the influence of anxiety on the levels of blood pressure and heart rate during dental treatment.

\section{Methodology}

This research was approved under the protocol 0508/2007 by the Committee for Ethics in Research involving Human Beings at Medicine College in São José do Rio Preto, São Paulo. The subjects of the research who agreed in participating signed the Statement of Informed Consent (IC), according to resolution 196/96 of the National Council for Ethics in Research of the Health Ministry.

The sample consisted of 60 volunteers randomly selected, as demand for voluntary screening service of the Dentistry Clinic in Rio Preto University Center - UNIRP, São José do Rio Preto, São Paulo, during the period from March to November in 2007 . These volunteers were evaluated at the clinic, always by the same examiner and answered the questions contained in the anamnesis form. This form has allowed the identification of signs and symptoms of functional alterations of the stomatognathic system and the conduction of intra and extra oral physical examinations, for the evaluation of the hypertension and heart rate presence. It is noteworthy that patients who had any of the aforesaid changes were excluded.

For measurements of blood pressure (BP) and heart rate (HR), in millimetres of mercury $(\mathrm{mmHg})$ the number of heartbeats per minute (bpm), respectively, an aneroid sphygmomanometer (Premium ${ }^{\circledR}$, Glicomed, Rio de Janeiro) and a professional cardiologic stethoscope (Premium, Glicomed, Rio de Janeiro) were used, in 4 distinct moments (Table 2). The method used to measure BP and HR was based on Andrade and Ranali (10).

The treatments were performed on volunteers in dental specialties of Maxillofacial Surgery and Traumatology, Endodontics, Periodontics and Dental Surgery.

To evaluate the patients' anxiety level, before the dental treatment, the dental anxiety scale (DAS) of Corah (11) was used, accompanied by a form containing issues about patient identification, harmful habits, diseases, frequency to dental visits and cardiovascular parameters. The Corah scale consists of four questions with five possible answers, which characterize the patient anxiety level in response to different situations that involve a visit to the Dental Surgeon (DS), and it is applied prior to dental treatment (Table 1).

Table 1. Dental Anxiety Scale (DAS) translated into Portuguese language by Pereira et al. (12) and used in this Brazilian sample.

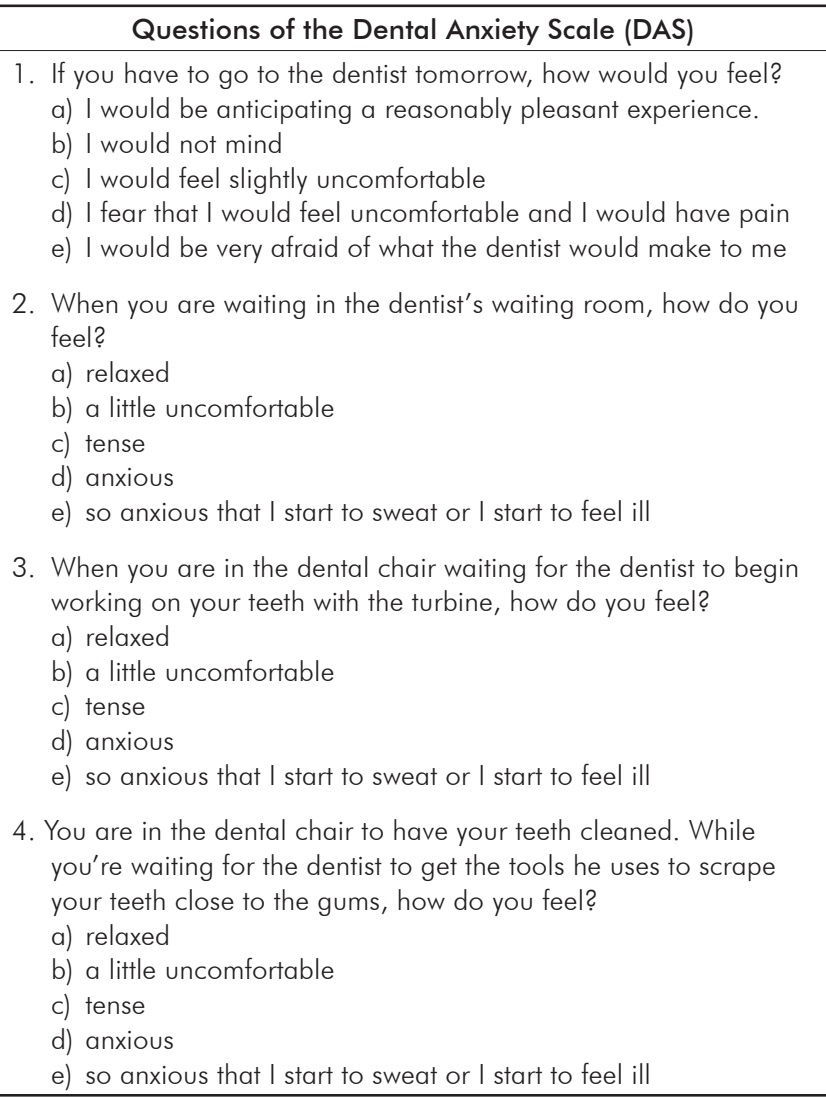

Table 2. Presentation of the moments in which the blood pressure $(\mathrm{BP})$ and heart rate (HR) measurements were taken from the research volunteers.

Moments of the BP and HR measurements

1. Initial: first measurement, with the patient still in the waiting room, trying to characterize the basal BP.

2. In the dental chair: held before the treatment, with the patient sitting in the dental chair. This measure aimed to establish a relation between the variation of $\mathrm{BP}$ and $\mathrm{HR}$ and the dental environment.

3. After anesthesia: held immediately after the injection of the local anesthetic, with the objective of establishing the relation between the anesthetic procedure and the variation of BP and HR.

4. Ten minutes after the anesthesia: to associate the pain control by means of anesthesia with variation of BP and HR. 
To quantify the answers, the following values were established: $\mathrm{a}=1, \mathrm{~b}=2, \mathrm{c}=3, \mathrm{~d}=4, \mathrm{e}=5$. Based on the Corah criterion (11), the sum of the values assigned to each answer, the possible interval score may vary between 4-20 points, and the level of anxiety classified in nil, low, moderate and exacerbated.

The collected data were initially stored in an Excel $^{\mathbb{B}}$ spreadsheet (Microsoft Office, 2003) and, then we held a descriptive statistical analysis using the Epi $\operatorname{Info}^{\circledR}$ version 3.5.1. According to the paired distribution among the subjects of this study, we used the Kruskal-wallis Test, confirmed by the Friedman Test in the Bioestat version 3.0.

\section{Results}

The results obtained showed that from the 60 volunteers who participated in the research, $35(58.4 \%)$ belonged to the female gender with a mean age of 23 years and incomplete elementary education. According to the aspects related to health, most of them did not have the habit of smoking, but presented a family history of systemic diseases, such as diabetes Mellitus, hypertension, cancer, heart disease, pulmonary emphysema. The frequencies to dental visits answered by patients may be observed in Figure 1. During the period of the volunteers' follow-up no systemic change that could interfere with the results of the study was detected.

The relation between anxiety and gender revealed that 17 $(48.6 \%)$ women had mild anxiety, followed by $12(34.6 \%)$ who were very anxious. The relation between anxiety and the age group revealed that $13(21.6 \%)$ volunteers aged between 18 to 30 years showed mild anxiety, followed by 8 $(13.4 \%)$ very anxious.

In evaluating the relation between anxiety and apparent pain before treatment, it was possible to observe that 54 $(90.0 \%)$ showed no pain. Three patients $(5.0 \%)$ who reported effective pain presented a mild anxiety level.

The anesthetic solutions used during the treatments showed that the $3 \%$ prilocaine with felypressin was the most used in $38(63.0 \%)$ patients, and $16(27.0 \%)$ showed low anxiety immediately after the injection. Lidocaine with epinephrine was administered to $16(27.0 \%)$ volunteers observing low anxiety in $7(12.0 \%)$, as well as the mepivacaine without vasoconstrictor.

Figure 2 shows the non-statistically significant difference concerning to systolic BP at first time and, after the application of the anesthetic, whereas the levels of anxiety (Kruskal-wallis Test, $P>0.05$ ). Figure 3 shows the variation (mean \pm standard deviation) of diastolic BP in accordance to the anxiety level, in different measures performed in this study, considering the different anxiety level observed. Figure 4 shows the HR of volunteers in different moments of the visits. We can observe that the HR practically does not change as a function of anxiety. There is a slight alteration of the post-anesthesia non-significant HR, returning to normal after 10 minutes.

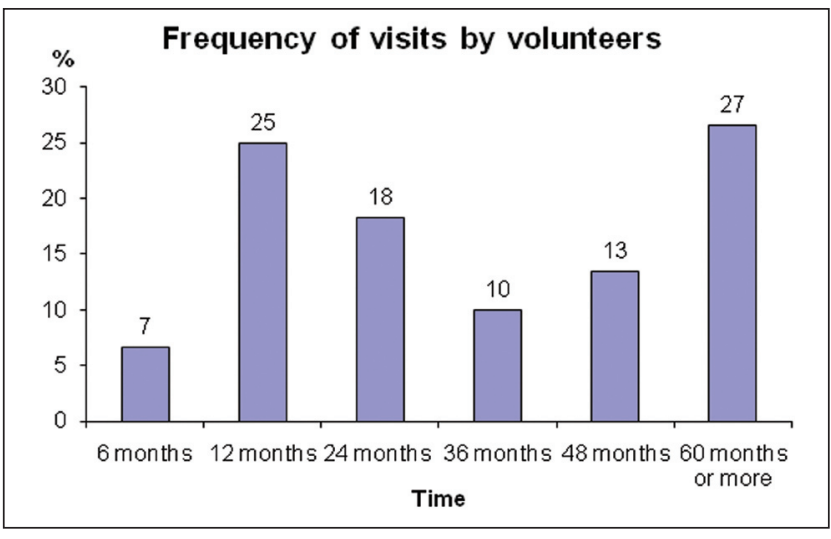

Fig. 1. Frequency distribution of volunteers' dental visits in the research study.

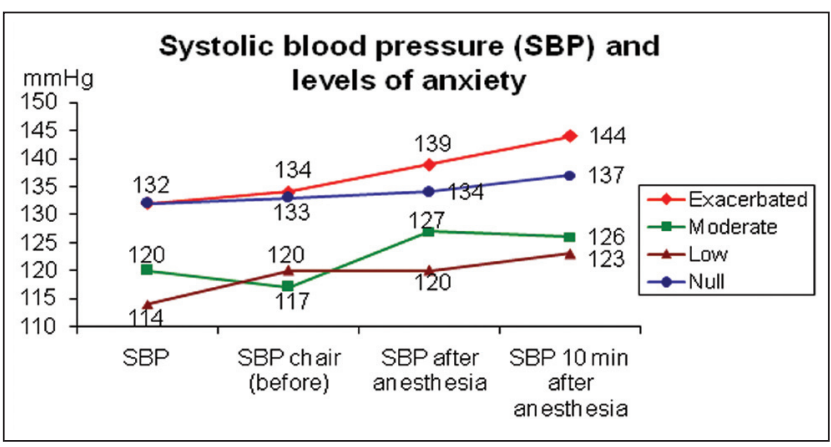

Fig. 2. Association between systolic blood pressure (in $\mathrm{mmHg}$ ) and anxiety levels.

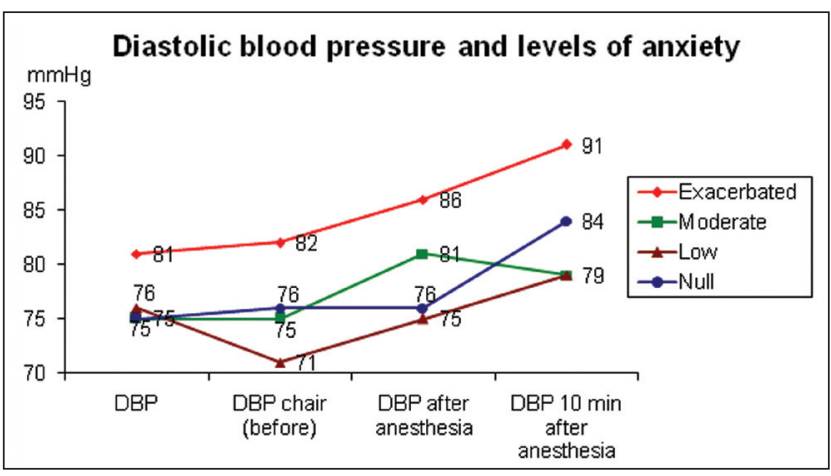

Fig. 3. Association between diastolic blood pressure (in $\mathrm{mmHg}$ ) and anxiety levels.

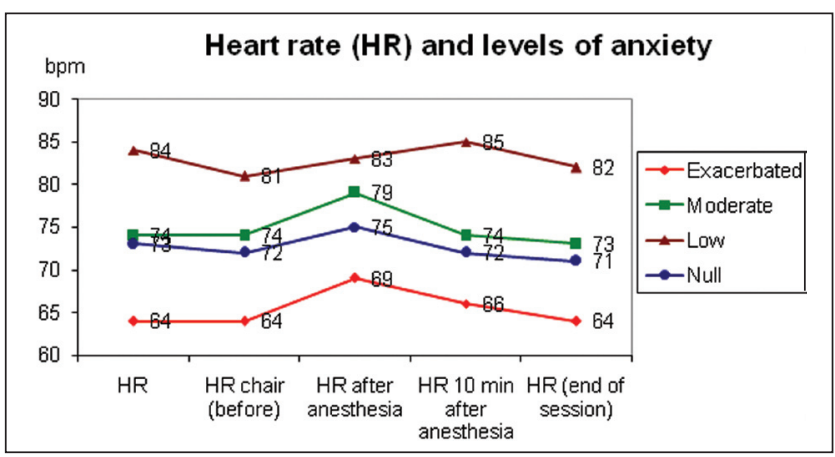

Fig. 4. Association between heart rate (bpm) and anxiety levels. 


\section{Discussion}

This research is related to the influence of anxiety on the cardiovascular parameters (BP and HR) in different stages of dental treatment. The authors chose the DAS proposal by Corah (11) and translated by Pereira et al. (15) to diagnose the state of anxiety in dental patients. This scale is recommended because of the facility to be used in addition to serving as a predictor for the Dental Surgeon (DS) to establish an appropriate treatment for the patient $(8,13,14)$.

The information provided by graduate students before and after dental treatment is efficient for those patients who presented with moderate anxiety, because we noticed reduction of the patients expectation in relation to the treatment performed. This finding reinforces the importance of DS to verbalize so early and safe to the patient about the procedures to be performed in each visit, thus avoiding the fear of the unknown $(1-3,12,13,15)$.

According to Schüller et al. (2) eager patients to dental treatment remain more than 3 years without attending the dental office. The information suggests that it is associated with the fact that the patients relate the dental visits to the feelings of fear and anxiety, perhaps to have previous negative experience, especially during childhood $(1,6,8,13)$.

Bottan et al. (3), reported that the greater the level of patient anxiety, lesser will be the percentage of preventive visits frequented by the same. Thus, the DS must be prepared to evaluate the patient reactions and to place psychological strategies to reduce the anxiety of the same (16), motivating them to attend regular visits. In our study, the patients received information about the diagnosis and the procedure that was performed, as recommended by other authors $(12,14)$.

The DAS used in this study showed that young women had low anxiety level. This result was also found by other researchers (13-14,17-18). However, there are studies that have shown that anxiety can occur in a fair manner in both genders $(15,19)$.

When analyzing anxiety and age group, statistically significant difference was detected in volunteers who were aged between 18 and 30 years classified as low anxiety level. For Rocha (20) students from public and private schools between 14 and 26 years were classified as being of low anxiety, corroborating with the results obtained in this study. However, Udoye et al. (21) revealed that the anxiety level increases in dental patients above 24 years of age.
Studies have associated anxiety with pain, because the anxiety increases sympathetic activity, thus producing endogenous adrenaline, causing increased pain through the awareness of nociceptors (7). This association was not observed in this study, because the results obtained showed that the $3(5 \%)$ patients who reported pain, were in the group of low anxiety patients, leading us to suggest that there is a direct relation between the anxiety with the elevation of painful sensation.

Chaves et al. (14) concluded that there were no significant changes between anxiety and BP for both genders. Conceição et al. (22), did not find statistically significant differences in BP and HR of anxious and non-anxious patients. Such data corroborate the results found in this study, because none of the parameters evaluated (systolic, diastolic BP or HR) showed statistically significant differences $(P>0.05$, Friedman test), when compared to initial BP with the other measures within the four anxiety levels. It should be noted that the HR and BP are commonly used as dependent variables in behavioral studies and serve as parameters for the evaluation of anxiety level (23).

In the present study significant changes in the HR and $\mathrm{BP}$ were not found in relation to 3 different anesthetic salts used during dental procedures performed in the volunteers. According to Andrade (24), the use of anesthetics with vasoconstrictor promotes pain control and avoids the anxiety. On the other hand, Palma et al. (25) when studying the variation of BP by using local anesthetics without vasoconstrictor found that it proved to be more superficial and less lasting, generating pain and anxiety in the patients, thus producing a significant increase in BP in normotensive patients.

\section{Conclusions}

As compared to the results, the data of the study revealed that there was no difference in the behavior of the systolic and diastolic blood pressure in relation to anxiety and pain level, measured at different times of the dental treatment. The heart rate did not change during the dental treatment in relation to the anxiety level presented by the patient. It is suggested that further research should be conducted in this area of knowledge in the search to disseminate more widely the information about anxiety to the professionals who work in the daily practice of clinical dentistry. Lanka. Int Dent J 2002;52:151-5.

2. Schüller AA, Willumsen T, Holst D. Are the differences in oral health and oral health behavior between individuals with high and low dental fear? Commun Dent Oral Epidem 2003;31:116-21.

3. Bottan ER, Oglio JD, Araújo SM. Ansiedade ao tratamento odontológico em estudantes do ensino fundamental. Pesq Bras Odontoped Clín Integr 2007;3:241-6.

4. Rodrigues RV. Correlação entre ansiedade e dor com a pressão arterial e a frequência cardíaca durante o atendimento odontológico de urgência [dissertation]. Piracicaba (SP): Faculdade de Odontologia de Piracicaba da UNICAMP; 2004. 
5. Kanegane K, Penha SS, Borsatti MA, Rocha RG. Ansiedade ao tratamento Odontológico no atendimento de rotina. RGO 2006;2:111-4.

6. Góes MPS, Domingues MC, Couto, GBL, Barreira AK. Ansiedade, medo e sinais vitais dos pacientes infantis. Odontol Clín Cient 2010;9:39-44.

7. Malamed SF. Medical emergencies in dental office. $6^{\text {th }}$ ed. St. Louis: Mosby; 2007.

8. Oliveira PC, Zanetta-Barbosa D, Souza HJ, Batista JD, Ranali J, Costa MDMA et al. Avaliação do nível de ansiedade e dor de pacientes em urgências endodônticas e sua influência sobre parâmetros cardiovasculares. Cienc Odontol Bras 2007;4:70-5.

9. Mask Jr AG. Medical management of the patient with cardiovascular disease. Periodontol 2000;23:136-41

10. Andrade ED, Ranali J. Emergências médicas em Odontologia. São Paulo: Artes Médicas; 2002.

11. Corah NL. Development of a dental anxiety scale. J Dent Res 1969;48:596.

12. Pereira LHMC, Ramos DLP, Crosato E. Ansiedade e dor em odontologia-enfoque psicofisiopatológico. Rev Assoc Paul Cir Dent 1995;49:285-90.

13. Kanegane K, Penha SS, Borsatti MA, Rocha RG. Ansiedade ao tratamento odontológico em atendimentos de urgência. Rev Saude Public 2003;37:786-92.

14. Chaves MA, Loffredo LCM, Valsecki-Júnior A, Chavez OM, Campos JADB. Estudo epidemiológico da ansiedade dos pacientes ao tratamento odontológico. Rev Odontol UNESP 2006; 35:236-8.

15. Vassend $O$. Anxiety, pain and discomfort associated with dental treatment. Behav Res Ther 1993;31:659-66.

16. Possobon RF, Carrascoza KC, Moraes ABA, Costa Jr AL. O tratamento odontológico como gerador de ansiedade. Psicol Estud 2007;12:609-16.

17. Smyth JS. Some problems of dental treatment. Part 1. Patient anxiety: some correlates and sex differences. Aust Dent J 1993;38:354-9.

18. Taguchi MF, Araújo IC, Silva AJM, Shimono T. O medo frente ao tratamento odontológico. RGO 1993;41:138-42.

19. Maggirias J, Locker D. Five-year incidence of dental anxiety in an adult population. Community Dent Health 2002;19:173-9.

20. Rocha LML. Avaliação do nível de ansiedade e medo em alunos das escolas pública e privada no município de Belém-PA [dissertation]. São Paulo (SP): Faculdade de Odontologia, Universidade de São Paulo; 2003.

21. Udoye $\mathrm{Cl}$, Oginni AO, Oginni FO. Dental anxiety among patients undergoing various dental treatments in a Nigerian teaching hospital. J Contemp Dent Pract 2005;6:91-8.

22. Conceição DB, Schonhorst L, Conceição MJ, Oliveira Filho GR. Pressão arterial e a frequência cardíaca não são bons parâmetros para a avaliação do nível de ansiedade pré-operatória. Rev Bras Anestesiol 2004;54:769-73.

23. Moerman N, van Dam FS, Muller MJ, Oosting $H$. The Amsterdam preoperative anxiety and information scale. Anesth Analg 1996;82:445-51.

24. Andrade ED. Cuidados com o uso de medicamentos em diabéticos, hipertensos e cardiopatas. In: Anais do $15^{\circ}$ Conclave Odontológico Internacional de Campinas; 2003 Mar-Apr; Campinas; 2003. p. 104.

25. Palma FR, Lins LHS, Branco FP, Wygladala LG. Verificação da variação da pressão arterial pelo uso de anestésicos locais com vaso constritor. Rev Odonto Ciênc 2005;20:35-9. 